\title{
The influence of polar vortex ozone depletion on NH mid-latitude ozone trends in spring
}

\author{
S. B. Andersen and B. M. Knudsen \\ Department of Research and Development, Danish Meteorological Institute, Lyngbyvej 100, 2100 Copenhagen Ø, Denmark
}

Received: 28 November 2005 - Published in Atmos. Chem. Phys. Discuss.: 10 March 2006

Revised: 26 June 2006 - Accepted: 27 June 2006 - Published: 11 July 2006

\begin{abstract}
Reverse domain-filling trajectory calculations have been performed for the years 1993, 1995, 1996, 1997, and 2000 to calculate the spreading of ozone depleted air from the polar vortex to midlatitudes in spring. We find that for these years with massive Arctic ozone depletion the zonal mean total ozone column at midlatitudes is reduced with between 7 and 12 DU in the April-May period. The polar vortex and remnants have preferred locations which leads to longitudinal differences in the midlatitude ozone trends. Together with decadal variations in circulation the dilution of ozone depleted air may explain the major fraction of longitudinal differences in midlatitude ozone trends. For the period 1979-1997 the dilution may explain 50\% of the longitudinal differences in ozone trends and for the period 1979-2002 it may explain $45 \%$. The dilution also has a significant impact on the zonal mean ozone trends in the April-May period. Although uncertainties are large due to uncertainties in the ozone depletion values and neglect of ozone depletion in other years than 1993, 1995, 1996, 1997, and 2000 we have tried to calculate the size of this effect. We estimate that dilution may explain 29\% of the trend in the period 1979-1997 and 33\% of the trend in the period $1979-2002$ as a lower limit.
\end{abstract}

\section{Introduction}

Massive ozone depletion inside the Arctic vortex has frequently occurred during the past decade resulting in dilution of the Northern Hemisphere ozone layer down to midlatitudes. Several studies have tried to quantify the impact of polar ozone depletion on midlatitude zonal average ozone changes in both hemispheres (Chipperfield, 2003; Millard et al., 2003; Marchand et al., 2003; Ajtic, 2004; Fioletov

Correspondence to: S. B. Andersen

(sba@dmi.dk) and Shepherd, 2005). Observations by satellite instruments as for example the merged TOMS/SBUV data show that the largest spring ozone depletions over the northern and southern midlatitudes occur over Europe and Russia, except for large depletions south of $55^{\circ} \mathrm{S}$ (WMO, 1999). It is well known that longitudinal differences in circulation trends can explain a substantial fraction of the longitudinal ozone trend differences in winter (Hood and Zaff, 1995; McCormack and Hood, 1997; Peters and Entzian, 1998; Hood et al., 1999). Hood et al. (1999) thus found that $330 \mathrm{~K}$ PV trends indicative of trends in Rossby wave breaking and quasi-stationary wave variability correlate geographically with trends in total ozone. Several studies indicate that trends in the $300 \mathrm{hPa}$ geopotential height from 1979-1992 explain around half the longitudinal trend differences from 1979-1992 all the year round (Entzian and Peters, 2000). They do, however, not explain the strong April and May trends over Scandinavia and especially Russia which have occurred during the past decade. We have earlier shown that these longitudinal differences in trends may be explained by a combination of decadal variations in the circulation and transport of ozone depleted air from the polar vortex focussing on the polar ozone depletion in the two years 1993 and 1997 (Knudsen and Andersen, 2001). In this paper we extend the study and show that the explanation holds for more years and is related to the fact that the polar vortex and its remnants have preferred locations where the contained ozone depletion enhances the midlatitude trends. We will also investigate the influence of the polar ozone depletion on zonal average ozone trends. The study will concentrate on the Northern hemisphere midlatitudes $\left(30-60^{\circ} \mathrm{N}\right)$ in April and May. This period is interesting for several reasons; it is at the end of the winter where the accumulated Arctic ozone depletion is at its highest, the UV-radiation is relatively high and it is the growth period for many biological systems. 
Table 1. Start date and polar ozone depletion amount used in RDF calculations together with the resulting $30-60^{\circ} \mathrm{N}$ zonal mean dilution in April and May.

\begin{tabular}{lccccc}
\hline Year & 1993 & 1995 & 1996 & 1997 & 2000 \\
\hline Start date & 5 March & 30 March & 25 March & 4 April & 12 March \\
Polar ozone depletion & $68 \mathrm{DU}$ & 81 DU & $102 \mathrm{DU}$ & $79 \mathrm{DU}$ & $97 \mathrm{DU}$ \\
$30^{\circ}-60^{\circ} \mathrm{N}$ dilution & $7 \mathrm{DU}$ & $11 \mathrm{DU}$ & $12 \mathrm{DU}$ & $8 \mathrm{DU}$ & $11 \mathrm{DU}$ \\
\hline
\end{tabular}

\section{Dilution of polar vortex ozone depletion}

We have calculated the spreading of ozone depleted air from the polar vortex to midlatitudes in spring for the months April and May. This is what we will refer to as the "dilution". Part of the dilution is irreversible. The remainder is reversible due to for example movements of the vortex and vortex remnants. The calculations were performed for the years 1993, 1995 , 1996, 1997, and 2000.

Calculations of the dilution for April and May were performed using diabatic regridded reverse domain-filling (RDF) trajectory calculations covering the altitude region of the ozone depletion $(350-550 \mathrm{~K}$ potential temperature $(\theta)$ or approximately 13-22 km height). ECWMF 6 hourly analyses were used and the RDF calculations were made on a $111 \mathrm{~km}$ ( $1^{\circ}$ of latitude) equal area grid at 350, 375, 400, 425, $450,475,500,525,550 \mathrm{~K}$. The ozone depletions in 1993 , 1995, 1996, and 2000 were taken from Rex et al. (2004) while the ozone depletions from 1997 were taken from Knudsen et al. (1998b). Diabatic descent was calculated by the Morcrette (1991) radiation scheme. The descent calculations have been verified against observed tracers (Christensen et al., 2005). There is a good agreement except at levels below $400 \mathrm{~K}$. The ozone depletions were regridded every 7 th day. This introduces a horizontal mixing equivalent to a diffusivity of $1.65 \times 10^{3} \mathrm{~m}^{2} \mathrm{~s}^{-1}$ (Knudsen and Grooß, 2000; Hauchecorne et al., 2002). In the vertical the regridding is done by linear interpolation with respect to potential temperature within the $25 \mathrm{~K}$ (about $1 \mathrm{~km}$ ) vertical spacing. Using an aspect ration of 250 this corresponds to a diffusivity of $8.25 \times 10^{3} \mathrm{~m}^{2} \mathrm{~s}^{-1}$. Furthermore, the use of 6-hourly analysis, which are not dynamically consistent with each other, might introduce spurious mixing (Stohl et al., 2004; Schoeberl et al., 2003).

The calculations started on different dates each year before the polar vortex started to diminish in size. Start dates of the RDF-calculations may bee seen in Table 1. Mean values of the regridded depletions for April and May are calculated. The resulting column dilution is shown in Fig. 1. It is seen that the major part of the dilution reaching midlatitudes is over Russia an Scandinavia. The zonal mean dilution is between 7 DU and 12 DU and may be seen in Table 1.

By the end of the calculations on 31 May, some of the depletion had descended below $350 \mathrm{~K}$ or entered the tropo- sphere and was neglected (e.g. 9\% in 1993). Inaccuracies in the RDF mass advection on the other hand lead to apparent increases (up to 27\%) in the total amount of depletion, but calculated column depletions have been scaled to keep the total depletion constant. Photochemistry leads to recovery from ozone depletion, but has been neglected here. For example in 1997 the recovery in May is $12 \%$ of the total depletion (Knudsen and Gross, 2000). However, the average recovery for April and May is considerably smaller. The biggest uncertainty on the dilution calculations probably comes from determination of the end-of-winter ozone depletions. Rex et al. (2006) used an upper limit of 20 DU uncertainty on the column depletion. The uncertainties on individual levels are even relatively larger.

In Fig. 2 the modeled ozone mixing ratios are compared to ozone sondes from Scoresbysund $\left(70.5^{\circ} \mathrm{N}, 338.0^{\circ} \mathrm{E}\right)$. The agreement is good, except perhaps for the top levels, where the neglect of photochemistry could lead to an overestimation of the ozone mixing ratios. The RDF calculations have also been performed without the vortex depletions by adding the calculated depletion (Knudsen et al., 1998a) to the observed ozone mixing ratios on the initial day (11 April 1997). The figure shows that this would lead to far too large ozone mixing ratios, when Scoresbysund was inside the vortex remnants, as it was on the 9 and 16 May 1997.

By picking the years 1993, 1995, 1996, 1997, and 2000 we have included the major part of the vortex depletion. It has been shown that at $475 \mathrm{~K}$ the depletion in the winters 1991/1992 and 1988/1989 was small (Braathen et al., 2000), and only in the winter 1989/1990 ozone depletions comparable to the depletion in 1993 have been found. In the winter 1990/1991, 1993/1994, 1997/1998, 1998/1999, 2000/2001 and 2001/2002 little PSC activation has been predicted, so little ozone depletion is expected (Manney et al., 2005; Rex et al., 2004). In earlier winters the depletion potential is considerably reduced due to smaller amounts of chlorine and bromine. These considerations are in line with the March $63^{\circ}-90^{\circ} \mathrm{N}$ averaged total ozone variations (Newman et al., 1997), although the interpretation of these averages with respect to ozone depletion are complicated by movements of the polar vortex. 


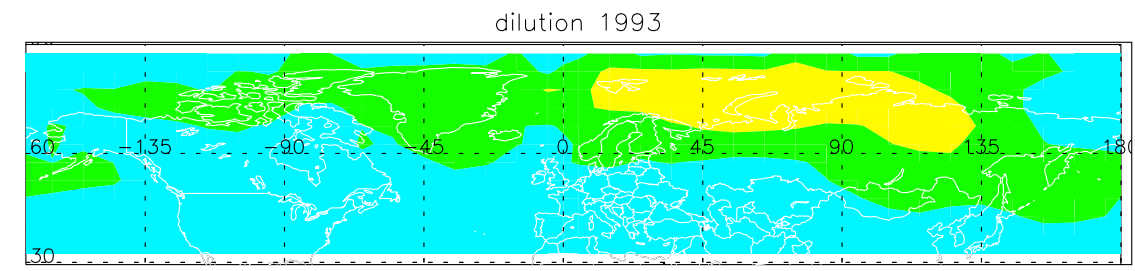

dilution 1995

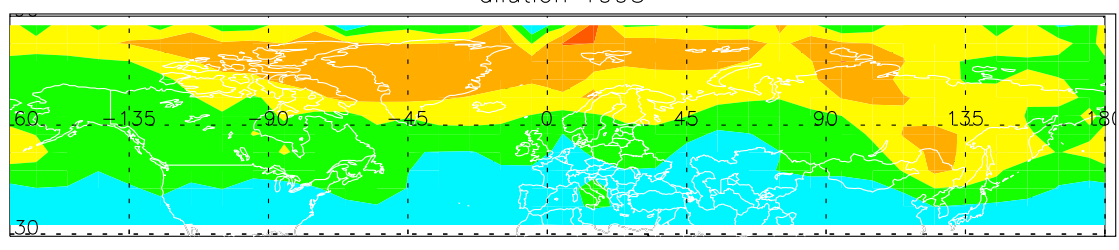

dilution 1996

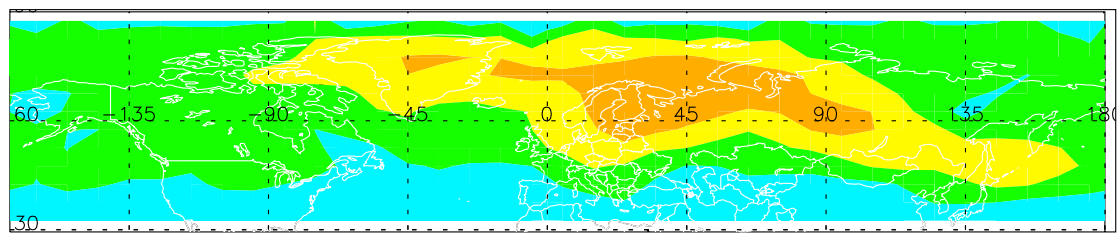

dilution 1997

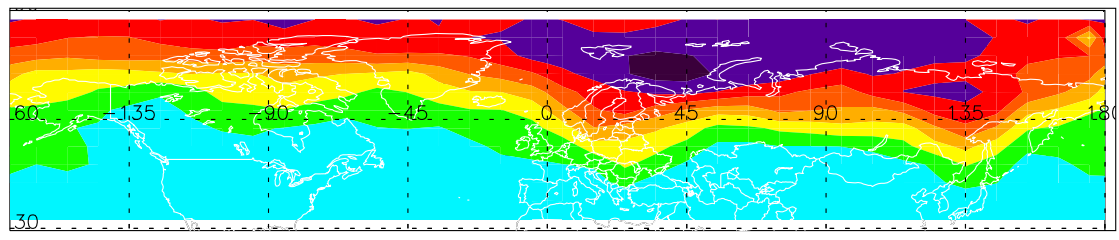

dilution 2000

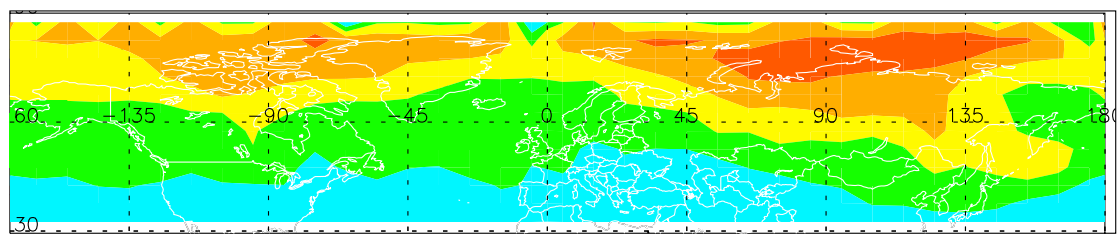

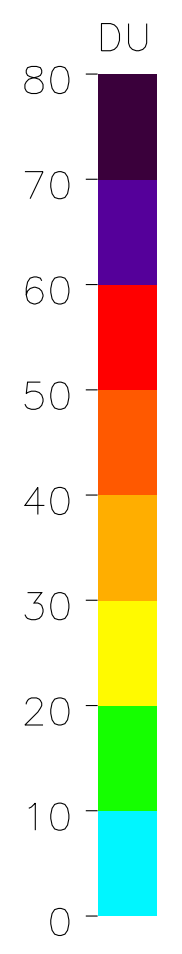

Fig. 1. April-May averages of the ozone depletion originating from the polar vortex in 1993, 1995, 1996, 1997, and 2000. $5^{\circ}$ latitudelongitude boxes were used. In 1997 the total depletion was largest and the vortex broke up latest, so that the mixing to lower latitudes was weakest.

\section{Vortex position}

To see whether the preferred positions for the vortex and its remnants over Scandinavia and Russia found in the dilution calculations are valid also for a longer period and to see what the influence is in March, the vortex occurrence frequency at any given point is calculated for the years of strongest vortex depletion: 1993, 1995, 1996, 1997, and 2000, and also for other years 1979-2000. The edge of the vortex is determined as where the PV gradient with respect to equivalent latitude (Nash et al., 1996) is largest. When the average wind speed at the edge of the vortex gets below $15.2 \mathrm{~ms}^{-1}$ for at least two consecutive days the vortex is considered broken down. Hereafter the equivalent latitude of the edge of the vortex remnants is kept constant, i.e. the area enclosed by the vortex remnants is kept konstant. If the vortex decreases substantially in size during the last 5 days before break-up, the largest size during these 5 days is used. As shown by Knudsen and Grooß (2000), the vortex remnants contain a lot of the depletion. In fact on May 25, 1997, the vortex remnants at $435 \mathrm{~K}$ defined in this way (PV $>17 \mathrm{PVU}$ (1 PVU $\left.=10^{-6} \mathrm{~K} \mathrm{~m}^{2} \mathrm{~s}^{-1} \mathrm{~kg}^{-1}\right)$ ) contain $42 \%$ of the depletion originating from the vortex. On 31 May 1993, the vortex remnants (PV $>16.9 \mathrm{PVU})$ contain $29 \%$ of the depletion. This definition of vortex remnants might contain air masses outside the region of largest PV gradients, but was selected to follow a larger part of the dilution. The statistic was calculated for $475 \mathrm{~K}$ because in some years no vortex exists in March at $435 \mathrm{~K}$. The calculation is based on ERA-40 data, but did not go further back than 1979 because the vortex 


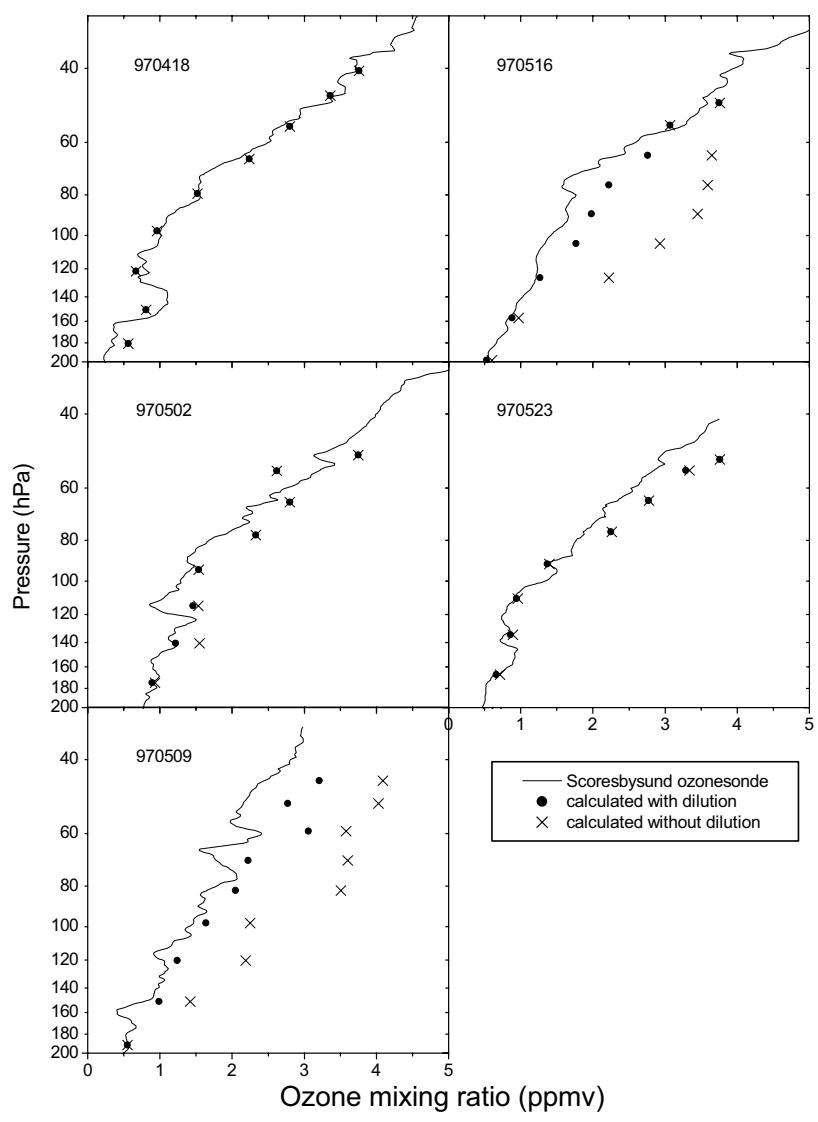

Fig. 2. Comparison of modelled ozone mixing ratios (circles) with ozonesonde observations (line). The crosses show what the result would be without ozone depletion.

generally gets weaker backwards in time. Karpetchko et al. (2005) arrive at similar occurence frequencies for March based on the whole ERA40 period.

Figure 3 shows the frequency of the occurrence of the vortex and its remnants in March, April, and May. In all 3 months the most likely occurrence of the vortex (remnants) in the midlatitudes is Europe and Eastern Russia both during the years with most vortex depletion and during the other years.

\section{Longitudinal ozone trends}

To calculate ozone trends the merged TOMS/SBUV version 7 data set with a resolution of $5^{\circ} \times 10^{\circ}$ was used (Miller et al., 2002). A newer version 8 data set exists which should be more applicable to absolute trend studies. This dataset however has a lower longitudinal resolution which makes it less suited to study longitudinal differences. Two different periods have been analyzed. First the period 1979-1997, which is the period that shows the largest longitudinal differences. In addition the analysis has been updated to include the period 1979-2002. Figures 4 and 5 show the trend from 30- $90^{\circ} \mathrm{N}$. However the region we focus on is the midlatitudes $30-60^{\circ} \mathrm{N}$.

A multiple linear regression model was applied to the April and May average ozone column assuming a linear trend and including the quasi-biannual oscillation and solar cycle as independent variables:

$Y_{t}=a+b_{0} t+b_{1}$ sol $_{t}+b_{2} q b o_{t-l}+\epsilon$

$Y_{t}$ is the time series of April-May ozone data; $a$ is the overall mean, $t$ is the year, $b_{0} \ldots b_{n}$ are the coefficients of the explanatory variables, sol $_{t}$ represents the the 11-year solar cycle, $q b o_{t-l}$ represents the quasi-biannual oscillation lagged by $l$ months ( $l$ was obtained by optimization of $b_{2}$ ) and $\epsilon$ is the residual.

The resulting trends may be seen in Figs. 4a and 5a. Trends calculated in the period 1979-1997 vary between $-2 \% /$ decade and $-9 \% /$ decade while trends calculated between 1979 and 2002 vary between $-2 \%$ /decade and $-6 \% /$ decade. The same pattern in the longitudinal variation is seen, although less pronounced for the period 1979-2002. This is probably due to very small ozone depletions in the Arctic vortex in most of the later winters except 2000 (Manney et al., 2005).

To calculate the effect of circulation changes and vortex depletions on the ozone trends, the ECMWF $250 \mathrm{hPa}$ geopotential as well as the dilution in 1993, 1995, 1996, 1997 and 2000 (zero in other years) is used instead of the linear ozone trend in the regression model:

$Y_{t}=a+b_{1}$ sol $_{t}+b_{2} q b o_{t-l}+b_{3} H_{t}+b_{4} d i l_{t}+\epsilon$

$H_{t}$ is the geopotential height and $d i l_{t}$ is the dilution.

Figures $4 b$ and $5 b$ shows the trend in ozone that may be explained by the trend in the $250 \mathrm{hPa}$ geopotential taken from ECWMF analysis. It is clear that the height trend helps explain that the downward ozone trend is weak south of Greenland and strong over the UK. But it does not explain the strong trends over e.g. Scandinavia and Russia. At midlatitudes $\left(30-60^{\circ} \mathrm{N}\right)$ the $250 \mathrm{hPa}$ geopotential height has a spatial correlation with the trends in total ozone of 0.57 and may thus explain $32 \%$ of the longitudinal differences in ozone trends for the period 1979-1997. For the period 1979-2002 trends in $250 \mathrm{hPa}$ geopotential height may explain $27 \%$ of the longitudinal differences (correlation 0.53) for the period 1979-2002. There is no significant trend in the zonal mean ozone due to changes in the $250 \mathrm{hPa}$ geopotential height.

Figures $4 \mathrm{c}$ and $5 \mathrm{c}$ shows the trend in ozone that may be explained by vortex depletion. This helps explain the strong downward ozone trends over Scandinavia and Russia. At midlatitudes $\left(30-60^{\circ} \mathrm{N}\right)$ the dilution may explain $50 \%$ (correlation 0.71 ) of the longitudinal differences in ozone trends for the period 1979-1997 and 45\% (correlation 0.67) for the period 1979-2002. In zonal mean the trend at midlatitudes related to dilution amounts to $-1.7 \%$ /decade ( $39 \%$ of the total trend) for $1979-1997$ and $-1.3 \% /$ decade (54\% of the total 


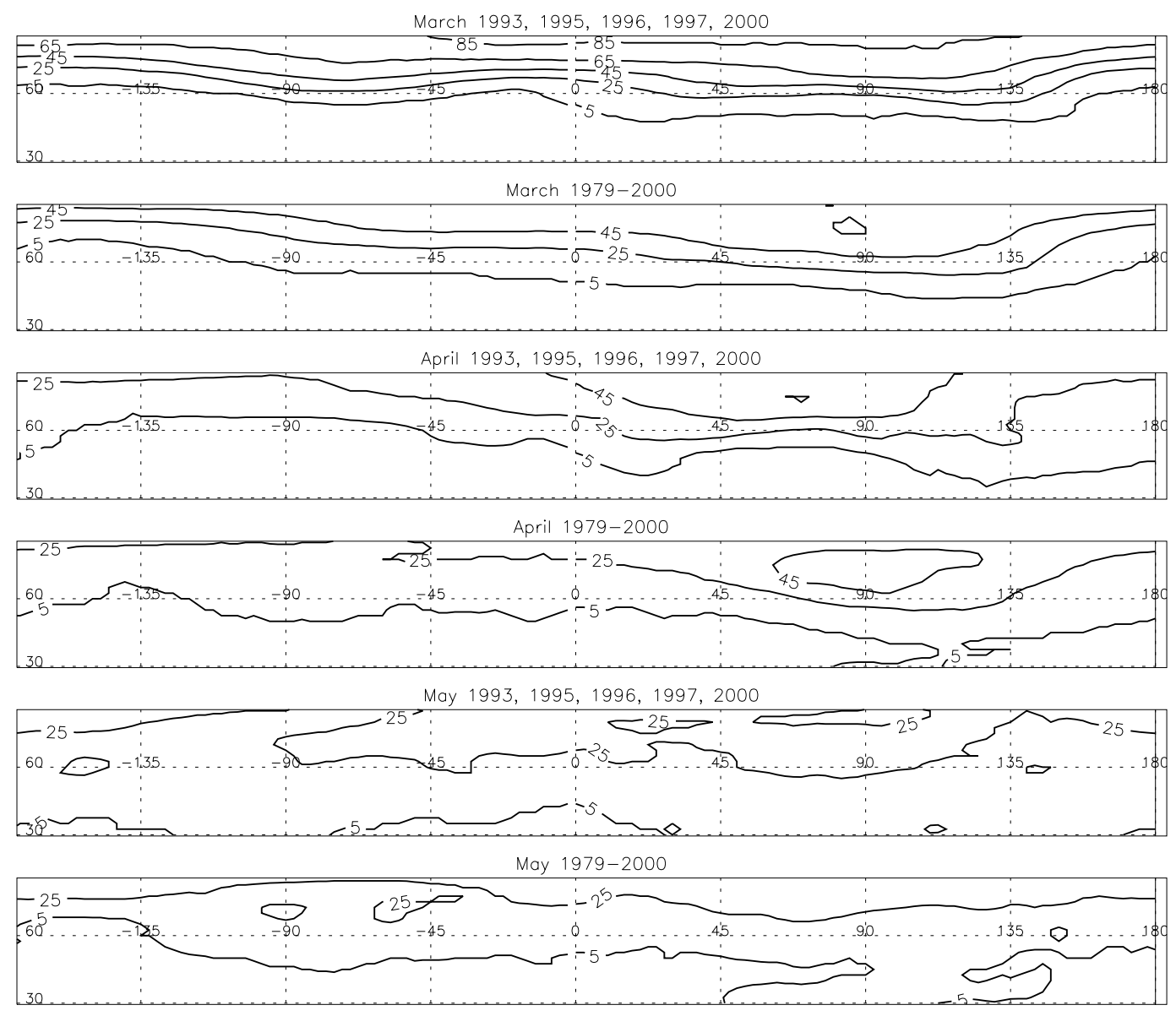

Fig. 3. Percentage occurrence frequency of the vortex (remnants) for 1993, 1995, 1996, 1997, and 2000 in March, April, and May, and for other years 1979-2000 in (d) March, (e) April, and (f) May. Contours at 5, 25, 45, ..\%.

trend) for 1979-2002 of the observed ozone trend. However there is a strong correlation between a linear decrease with time (or equivalent effective stratospheric chlorine (EESC) proxy) and the dilution proxy. Therefore these numbers may include some trend related to local ozone depletion out side the polar vortex and should therefore be regarded with some caution. Also the dilution may be correlated to low ozone due to less poleward transport in years with a strong vortex. By neglecting the vortex depletion in other years than 1993, 1995, 1996, 1997 and 2000 the effect of the vortex depletion will be underestimated.

In Figs. 4d and 5d the trends in panels (b) and (c) have been added and the combination explains the major part of the longitudinal trend variations. From $30^{\circ}-60^{\circ} \mathrm{N}$ it explains $80 \%$ of the variation until 1997 and $62 \%$ of the variation until 2002 , whereas the height trend alone only explains $32 \%$ and $27 \%$, respectively. The fact that the trends in panels (a) generally are more negative than the trends in panels (d) is due to e.g. local ozone depletion outside the vortex (Solomon et al., 1996). Figures $4 \mathrm{e}$ and $5 \mathrm{e}$ show the trend of the residuals which in zonal mean amounts to $-1.5 \%$ /decade and
$-0.6 \% /$ decade for the periods $1979-1997$ and $1979-2002$, respectively.

The underlying assumption in the calculations of the effect of the vortex depletions is that the position of the vortex and its remnants is independant of the ozone depletion itself. Another related shortcoming is the neglect of radiative cooling impacts of the ozone depletion. However, Prather et al. (1990) found that the reduction of the ozone transport into the troposphere (mainly through radiative descent) is only a minor fraction of the photochemical recovery during the Antarctic spring. These two errors probably only result in minor errors in the calculations.

\section{Zonal average ozone trends}

A complicating factor in determining the influence of dilution is that the dilution is correlated with the chlorine loading of the stratosphere and thus with local ozone depletion due to homogeneous chemistry. Since the local homogeneous ozone depletion is likely to be zonally symmetric, it is mainly the absolute contribution to the zonal mean trends 


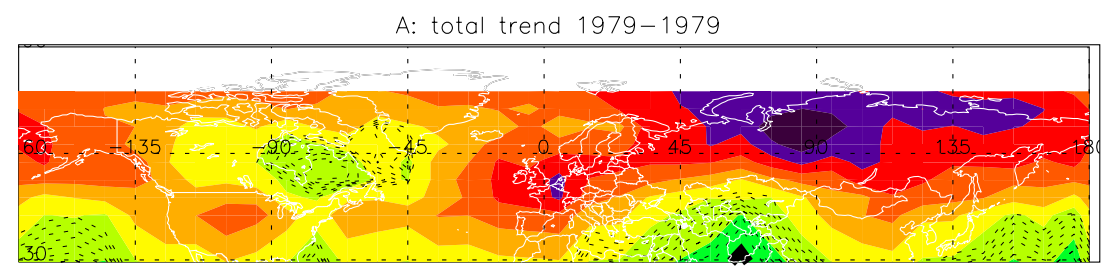

B: trend from change in height of $250 \mathrm{hPa} 1979-1979$

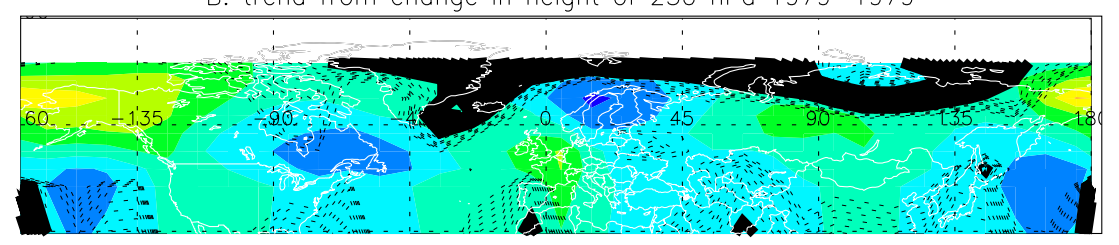

C: trend from vortex depletion 1979-1979

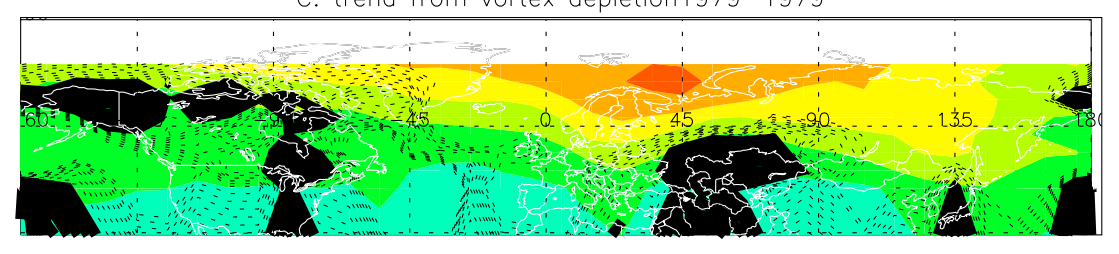

D: trend from height and vortex depletion 1979-1979

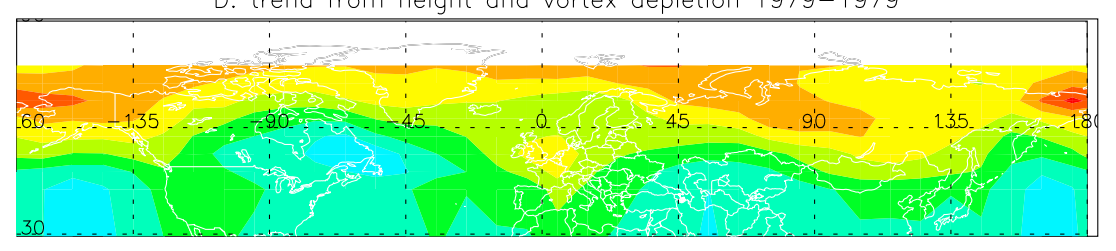

E: residual trend
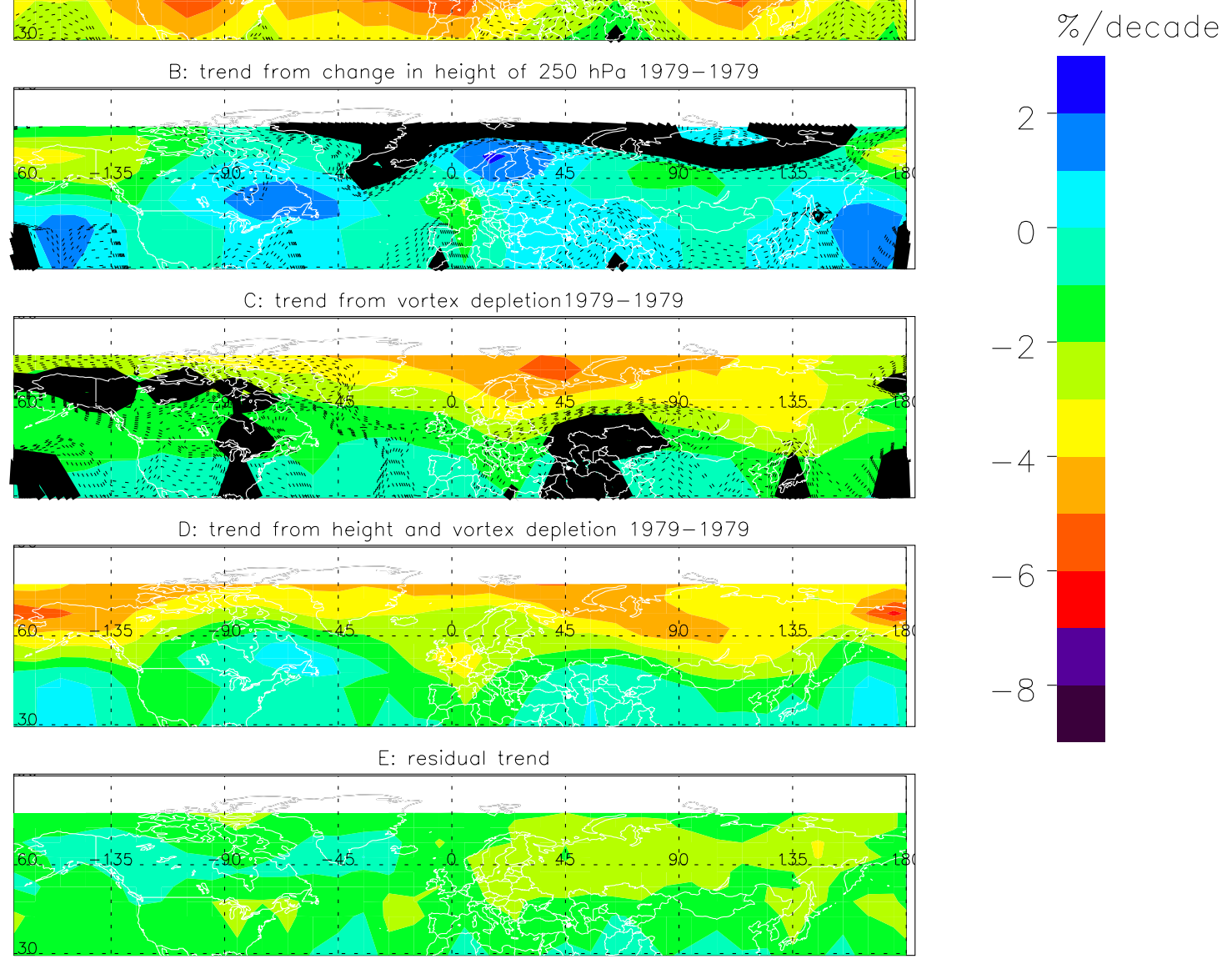

Fig. 4. (a) The April-May 1979-1997 ozone trend (\%/decade). (b) The ozone trend due to the trend in the $250 \mathrm{hPa}$ height. The height trends explains that the downward ozone trend is weak south of Greenland and strong over the UK. (c) The ozone trend due to the vortex depletions in 1993, 1995, 1996 and 1997. This helps explain the strong downward ozone trends over Scandinavia and Russia. (d) The sum of (b) and (c). This explains $80 \%$ of the midlatitude ozone trend variations in (a). The general offset between (a) and (d) is caused by e.g. local ozone depletion outside the vortex. Dots show if the trends are insignificant at the $2 \sigma$ level and solid black areas show if the trends are insignificant at the $1 \sigma$ level.

which is questionable. We have therefore tried to calculte the contribution of dilution to the ozone trends in an alternative way also. This has been done by simply subtracting the dilution from the total column ozone and calculating the trends of the resulting ozone fields using the following model:

$$
Y_{t}-d i l_{t}=a+b_{0} t+b_{1} \text { sol }_{t}+b_{2} q b o_{t-l}+\epsilon
$$

This results in smaller ozone trends as they might have been without dilution. By comparing these trends $\left(b_{0}\right.$ from Eq. 3) with the real trends ( $b_{0}$ from Eq. 1 ) we estimate that $29 \%$ of the midlatitude ozone trend in the period 1979-1997 and 33\% in the period 1979-2002 may be explained by dilution. Again the fact that we neglected vortex depletion in other winters than the five with most ozone depletion will lead to underestimation of the effect of dilution. Based on the ozone depletion values from 1992-2000 from Rex et al. (2004) we estimate that it leads to an underestimation of the effect of dilution by about $20 \%$. The largest uncertainty in these estimates probably comes from the uncertainty in the ozone depletion values of about $20 \mathrm{DU}$. We estimate that this results in an uncertainty of about $30 \%$ on the trend $\left(b_{0}\right.$ from Eq. 3).

Several other studies have tried to quantify the impact of polar ozone depletion on midlatitude zonal average ozone changes. Using a chemical transport model Chipperfield et al. (2003) found that $30-50 \%$ of year round trend from 


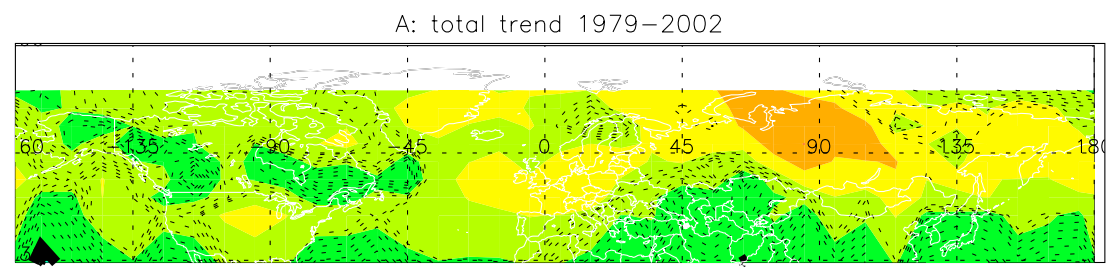

B: trend from change in height of $250 \mathrm{hPa} 1979-2002$

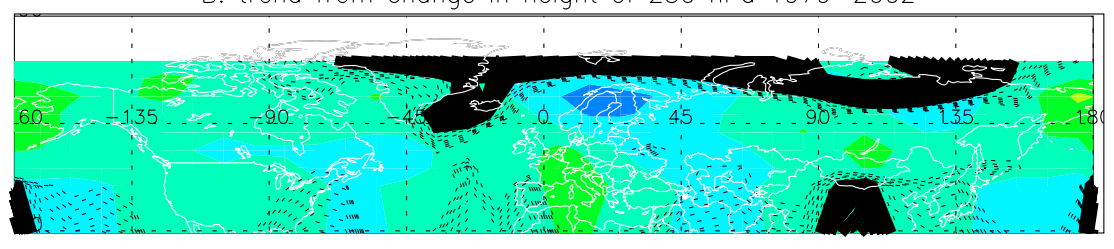

C: trend from vortex depletion1979-2002

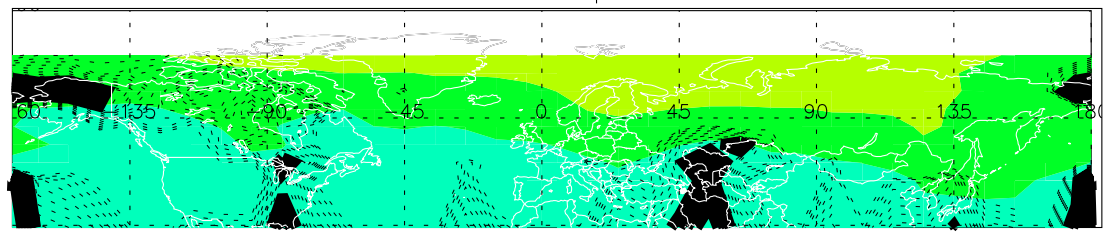

D: trend from height and vortex depletion 1979-2002

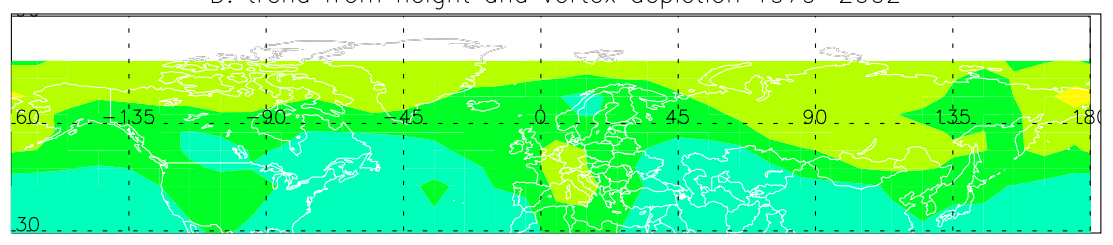

E: residual trend
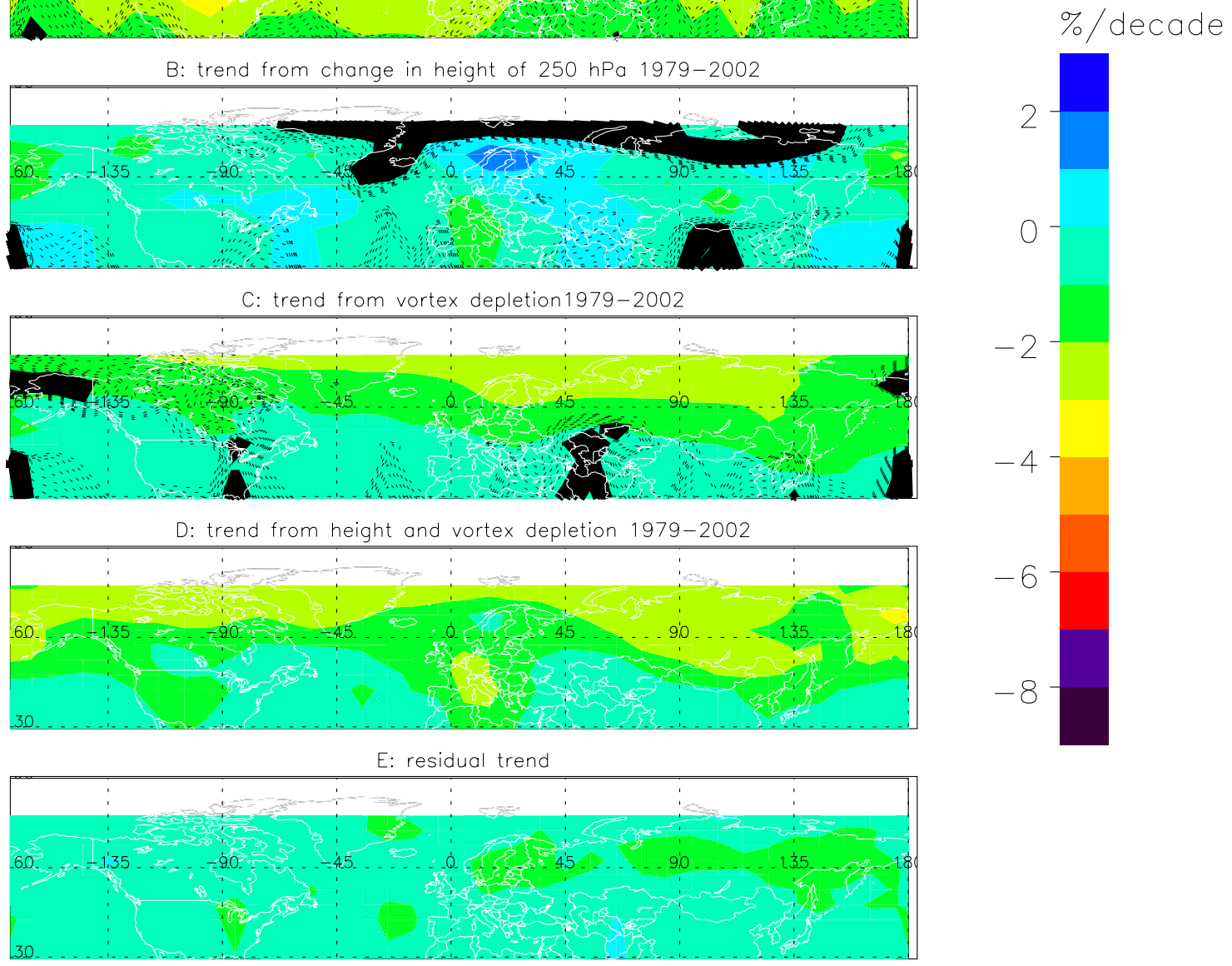

Fig. 5. Same as Fig. 4 for the period 1979-2002. (a) The April-May 1979-2002 ozone trend (\%/decade). (b) The ozone trend due to the trend in the $250 \mathrm{hPa}$ height. The height trends explains that the downward ozone trend is weak south of Greenland and strong over the UK. (c) The ozone trend due to the vortex depletions in 1993, 1995, 1996, 1997 and 2000. This helps explain the strong downward ozone trends over Scandinavia and Russia. (d) The sum of (b) and (c). This explains $62 \%$ of the midlatitude ozone trend variations in (a). The general offset between (a) and (d) is caused by e.g. local ozone depletion outside the vortex. Dots show if the trends are insignificant at the $2 \sigma$ level and solid black areas show if the trends are insignificant at the $1 \sigma$ level.

$35^{\circ}-60^{\circ} \mathrm{N}$ is due to dilution. Through a correlation study Fioletov and Shepherd (2005) found that $15 \%$ of the $35^{\circ}-60^{\circ} \mathrm{N}$ year round decline can be attributed to polar ozone depletion. The results presented here are valid for April-May only and can therefore not be compared directly, since the influence of dilution will be smaller year round due to further dilution and photochemical recovery of ozone. However, we find our results to be most in line with the first especially when considering that they are lower limits due to the neglect of polar ozone depletion in other years than the five worst winters. For the Southern Hemisphere Ajtic et al. (2004), neglecting photo-chemistry, find an upper limit of 16-19 DU to the reduction of SH 15 October-15 January total column ozone due to dilution. The neglegt of photo-chemisty in the Southern Hemisphere leads to much larger errors than in the Northern Hemisphere. In this paper we find a reduction 7-12 DU for the Northern Hemisphere.

\section{Conclusion}

We have shown that longitudinal differences in trends at midlatitudes in spring may be explained by a combination of decadal variations in the circulation and transport of ozone depleted air from the polar vortex. From $30^{\circ}-60^{\circ} \mathrm{N}$ it explains $80 \%$ of the variation until 1997 and $62 \%$ of the 
variation until 2002, the dilution of ozone depleted air alone explains $50 \%$ and $45 \%$ respectively. This is related to the fact that the polar vortex and its remnants have preferred locations where the contained ozone depletion enhances the midlatitude trends. In March to May the most likely occurrence of the vortex and remnants in the midlatitudes is Europe and Eastern Russia both during the years with most vortex depletion and during the other years.

We also investigated the influence of the polar ozone depletion on zonal average ozone trends. Although uncertainties are large due to uncertainties in the ozone depletion values and neglect of ozone depletion in other years than 1993, 1995, 1996, 1997, and 2000 we have tried to estimate the size of this effect. The dilution has a significant impact on the zonal average ozone trends in the April-May period. With a multiple linear regression model we find that the dilution may explain 39\% of the trend in the period 1979-1997 and $54 \%$ of the trend in the period 1979-2002. By calculting the effect of simply removing the dilutions we get the possibly more reliable estimates that that dilution may explain $29 \%$ of the trend in the period $1979-1997$ and 33\% of the trend in the period 1979-2002.

It is seen that the large vortex ozone depletions seen in the later years contribute to the observed spring ozone depletion over Europe and Russia mainly. Eastern Russia is at the climatological maximum of ozone, so the depletion here might not matter as much as the depletion over Europe, which is at the climatological minimum (longitudinally).

Acknowledgements. This work was done as part of the EUproject CANDIDOZ (EVK2-CT-2001-00133). We acknowlegde J. Morcrette for the radiation code, ECMWF for the meteorological analyses, The Ozone Processing Team of NASA for the TOMS/SBUV data and M. Rex for the ozone depletions.

Edited by: M. Dameris

\section{References}

Ajtic, J., Connor, B. J.,Lawrence, B. N., Boedcker, G. E., Hoppel, K. W., Rosenfield, J. E. and Heuff, D. N.: Dilution of the Antarctic ozone hole into southern midlatitudes, J. Geophys. Res., 109, D17107, doi:10.1029/2003JD004500, 2004.

Braathen, G. O., Müller, M., Sinnhuber, B.-M., von der Gathen, P., Kyrö, Mikkelsen, I. S., Bojkov, B., Dorokhov, V., Fast, H., Parrondo, C., and Kanzawa, H.: Temporal evolution of ozone in the Arctic vortex from 1988-89 to 1999-2000, paper presented at the SOLVE-THESEO 2000 Science Meeting, Palermo, 25-29 September 2000.

Chipperfield, M. P.: A three-dimensional model study of longterm mid-high latitude lower stratosphere ozone changes, Atmos. Chem. Phys., 3, 1253-1265, 2003,

http://www.atmos-chem-phys.net/3/1253/2003/.

Christensen, T., Knudsen, B.M., Streibel, M., Andersen, S.B., Benesova, A., Braathen, G., Claude, H., Davies, J., De Backer, H., Dier, H., Dorokhov, V., Gerding, M., Gil, M., Henchoz, B., Kelder, H., Kivi, R., Kyrö, E., Litynska, Z., Moore, D., Peters,
G., Skrivankova, P., Stübi, R., Turunen, T., Vaughan, G., Viatte,P. , Vik, A. F., von der Gathen, P., and Zaitcev, I.: Vortex-averaged Arctic ozone depletion in the winter 2002/2003, Atmos. Chem. Phys., 5, 131-138, 2005,

http://www.atmos-chem-phys.net/5/131/2005/.

Entzian, G. and Peters, D.: Seasonal longitude dependent total ozone variations induced by large scale wave structure of the geopotential field over the northern hemisphere, Proc. Quadrennial Ozone Symposium, Sapporo, 7-8, 3-8 July 2000.

Fioletov, V. E. and Shepherd, T. G.: Summertime total ozone variations over middle and polar latitudes, Geophys. Res. Lett., 32, L04807, doi:10.1029/2004GL022080, 2005.

Hauchecorne, A., Godin, S., Marchand, M., Heese, B., and Souprayen, C.: Quantification of the transport of chemical constituents from the polar vortex to midlatitudes in the lower stratosphere using the high-resolution advection model MIMOSA and effective diffusivity, J. Geophys. Res., 107(D20), 8289, doi:10.1029/2001JD000491, 2002.

Hood, L. L. and Zaff, D. A.: Lower stratospheric stationary waves and the longitude dependence of ozone trends in winter, J. Geophys. Res., 100, 25 791-25 800, 1995.

Hood, L. L., Rossi, S., and Beulen, M.: Trends in lower stratospheric zonal winds, Rossby wave breaking behavior, and column ozone at northern midlatitudes, J. Geophys. Res., 104, 23 321-24 339, 1999.

Karpetchko, A., Kyro, E., Knudsen, B.: Arctic and Antarctic polar vortices 1957-2002 as seen from the ERA-40 reanalyses, J. Geophys. Res., 110, D21109, doi:10.1029/2005JD006113, 2005.

Knudsen, B. M. and Grooss, J.-U.: Northern mid-latitude stratospheric ozone dilution in spring modeled with simulated mixing, J. Geophys. Res., 105, 6885-6890, 2000.

Knudsen, B. M., Lahoz, W. A., O'Neill, A., and Morcrette, J.J.: Evidence for a substantial role for dilution in northern midlatitude ozone depletion, Geophys. Res. Lett., 25, 4501-4504, 1998a.

Knudsen, B. M., Larsen, N., Mikkelsen, I. S., Morcrette, J.-J., Braathen, G. O., Kyr??., Fast, H., Gernandt, H., Kanzawa, H., Nakane, H., Dorokhov, V., Yushkov, V., Hansen, G., Gil, M., and Shearman, R. J.: Ozone depletion in and below the Arctic vortex for 1997, Geophys. Res. Lett., 25, 627-630, 1998 b.

Knudsen, B. M. and Andersen, S. B., Longitudinal variation in springtime ozone trends, Nature, 413, 699-700, 2001.

Manney, G. L., Krüger, K., Sabutis, J. L., Sena, S. A., and Pawson, S.: The remarkable 2003-2004 winterr and other recent warm winter in the Arctic stratosphere since the lata 1990s, J. Geophys. Res., 110, D4107, doi:10.1029/2004JD005367, 2005.

Marchand M., Godin, S., Hauchecorne, A., Lefèvre, F., Bekki, S., and Chipperfield, M.: Influence of polar ozone loss on northern midlatitude regions estimated by a high-resolution chemistry transport model during winter 1999/2000, J. Geophys. Res., 108(D5), 8326, doi:10.1029/2001JD000906, 2003.

McCormack, J. P. and Hood, L. L.: Modeling the spatial distribution of total ozone in northern hemisphere winter: 1979-1991, J. Geophys. Res., 102, 13 711-13 717, 1997.

McPeters, R. D., Hollandsworth, S. M., Flynn, L. E., Herman, J. R., and Seftor, C. J.: Long-term ozone trends derived from the 16-year combined Nimbus 7/Meteor 3 TOMS Version 7 record, Geophys. Res. Lett., 23, 3699-3702, 1996.

Millard, G. A., Lee, A. M. , and Pyle, J. A. , A model study 
of the connection between polar and midlatitude ozone loss in the Northern Hemisphere lower stratosphere, J. Geophys. Res., 108(D5), 8323, doi:10.1029/2001JD000899, 2003.

Miller, A. J., Nagatani, R. M., Flynn, L. E., Kondragunta, S., Beach, E., Stolarski, R., McPeters, R., Bhartia, P. K., DeLand, M., Jackman, C. H., Wuebbles, D. J., Patten, K. O., and Cebula, R. P.: A cohesive total ozone data set from the $\operatorname{SBUV}(/ 2)$ satellite system, J. Geophys. Res., 107(D23), 4701, doi:10.1029/2001JD000853, 2002.

Morcrette, J.-J.: Radiation and cloud radiative properties in the ECMWF operational weather forecast model, J. Geophys. Res., 96, 9121-9132, 1991.

Nash, E. R., Newman, P. A., Rosenfield, J. E., and Schoeberl, M. R.: An objective determination of the polar vortex using Ertel's potential vorticity, J. Geophys. Res., 101, 9471-9478, 1996.

Newman, P. A., Gleason, J. F., McPeters, R. D., and Stolarski, R. S.: Anomalously low ozone over the Arctic, Geophys. Res. Lett., 24, 2689-2692, 1997.

Pawson, S., Naujokat, B., and Labitzke, K.: On the PSC formation potential of the northern stratosphere, J. Geophys. Res., 100, $23215-23225,1995$.

Peters, D., and Entzian, G.: On the longitude-dependent total ozone trend over the Atlantic-European region in boreal winter months, in: Atmospheric Ozone, Proceedings of the XVIII Quadrennial Ozone Symposium, L'Aquila, Italy, 12-21 Sptember 1996, edityed by: Bojkov, R. D. and Visconti, G., 69-72, 1998.
Prather, M., Garcia, M. M., Suozzo, R., and Rind, D.: Global impact of the Antarctic ozone hole: dynamical dilution with a three-dimensional chemical transport model, J. Geophys. Res., 95, 3449-3471, 1990.

Rex M., Salawitch, R. J., von der Gathen, P., Harris, N. R. P., Chipperfield, M. P., and Naujokat, B.: Arctic ozone loss and climate change, Geophys. Res. Lett., 31, L04116, doi:10.1029/2003GL018844, 2004.

Schoeberl, M. R., Douglass, A. R., Zhu, Z., and Pawson, S.: A comparison of the lower stratospheric age spectra derived from a general circulation model and two data assimilation systems, J. Geophys. Res., 108(D3), 4113, doi:10.1029/2002JD002652, 2003.

Solomon, S., Portmann, R. W., Garcia, R. R., Thomason, L. W., Poole, L. R., and McCormick, M. P.: The role of aerosol variations in anthropogenic ozone depletion at northern midlatitudes, J. Geophys. Res., 101, 6713-6727, 1996.

Stohl, A., Cooper, O. R., and James, P.: A cautionary note on the use of meteorological analysis fields for quantifying atmospheric mixing, J. Atmos. Sci., 61, 1446-1453, 2004.

World Meteorological Organization (WMO), Scientific assessment of ozone depletion: 1998, Global Ozone Res. Monitor. Proj. Rep. 44, Geneva, 1999. 